\title{
PV for PV to accelerate carbon neutrality
}

\author{
Quanhong Yuan* \\ Guangdong University of Science \& Technology, Dongguan523083, China
}

\begin{abstract}
The cost of carbon neutrality is too expensive. How to find a cheaper and more feasible approach to realize it? This paper studies the innovative development mode of PV for PV-Max speed. Through the three-stage "PV for PV" development plan, After 2023, China's annual capacity can reach $400 \mathrm{GW}$, with a total investment of about $\$ 96$ billion. After 2032, China's PV installation can reach $4000 \mathrm{GW}$, annual power generation is $5200 \mathrm{TWh}$, and annual $\mathrm{CO} 2$ emission reduction is $4.4 \mathrm{Gt}$. After 2033, it will be an export period, with an annual export revenue of $\$ 54$ billion. By 2046, it will be able to export a total of $5300 \mathrm{GW}$, with an annual power generation of $6890 \mathrm{TWh}$. It will reduce the $\mathrm{CO} 2$ emissions of $10.2 \mathrm{Gt}$ for the world every year. If the PV plant is built in the three northern regions of China, combined with desertification control, the western desert will become a "green valley".
\end{abstract}

Keywords: Carbon neutrality; PV for PV; Desertification; Green revolution.

\section{Introduction}

The 120 member states of the United Nations Framework Convention on Climate Change (UNFCCC) are striving to achieve carbon neutrality by 2050[1]. China's CO2 emissions in 2019 was 10.5 GTon[2]. China is already the world's largest energy consumer and largest emitter of $\mathrm{CO} 2$, and is also the world's largest emitter of non- $\mathrm{CO} 2$ greenhouse gases (GHGs) emissions[3]. China accounts for the majority of the $48 \%$ of global emissions from countries that have pledged carbon neutrality (in law, in proposed legislation andin proposed policies)[4]. If China meets its 2060 emissions reduction commitments, it will avoid a quarter of a degree Celsius of global warming this century[5].

Nowadays more and more countries had taken steps to make renewable targets and create policies supporting renewable energy[6,7]. It is a major development task of all countries in the world to implement the new energy strategy and construct a clean, safe and efficient modern green energy system.

But the cost of carbon neutrality is expensive. According to the reports, China needs to invest $\$ 5 \sim 15$ trillion if it is to realize carbon neutral[8,9]. China's electricity system would need to reach net-zero CO2 emissions by 2050 , with more than $85 \%$ of all energy and more than $90 \%$ of electricity coming from non-fossil sources. Investment in the power sector alone needs to increase by $\$ 4$ trillion[10]. So the conventional way of development will takes long time, costs too much money, and is hard to implement.

\footnotetext{
* Corresponding author: 3301954919@qq.com
} 


\section{The analysis of $\mathrm{PV}$ for $\mathrm{PV}$ plan}

At present, the supply of photo-voltaic(PV) industry chain is mainly concentrated in the Chinese mainland. In 2019, China accounted for $67 \%, 97 \%, 79 \%, 71 \%$ and $59 \%$ of the global output of polysilicon, silicon wafer, battery, components and inverter.

$\mathrm{PV}$ is an industrialized product, with the possibility of large-scale self-replication. If the mode of PV for PV is adopted, the PV power generation is used to produce PV products. In this way, the rapid replication of PV can be utilized and the production can be rapidly increased. At present the energy consumption of all processes of the polycrystalline silicon $\mathrm{PV}$ is $1.2 \mathrm{kWh} / \mathrm{W}$. According to the average Chinese PV power generating capacity of 1.3 $\mathrm{kWh} / \mathrm{W}$.a, so It can be calculated that $1 \mathrm{~W}$ solar cells can be produced from $1 \mathrm{~W}$ PV power generation capacity every year, so the annual total PV production capacity will be doubled, and it is "zero carbon" and "zero pollution".

According to the projections, After 2050 China's total primary energy demand is 6 Gtce, and the proportion of clean energy consumption is $74 \%$. The total electricity demand is 14.1 trillion KWh (equivalent to 1.73 billion tce), and clean energy power generation is 13 trillion $\mathrm{KWh}[11,12]$. If one third of China's electricity $(4700 \mathrm{TWh})$ will be generated by PV in 2050. it will be calculated based on the average annual PV panel generation of $1.3 \mathrm{kwh}$ /W. China need to install PV 3616 GW, by the end of 2019 China PV power grid capacity is $204 \mathrm{GW}$, as a base, the PV doubled every year, 5 years later PV can grow up to $3200 \mathrm{GW}$.

The price of PV dropped $90 \%$ in the past ten years [13]. At present PV module market price has dropped to 1.3 yuan/W, according to the component price of 1.5 yuan/W, PV factory installed cost is 2.5 yuan/W (due to produce their own can save costs by more than $10 \%$ ). energy consumption of $\mathrm{PV}$ production is $1.2 \mathrm{kWh} / \mathrm{W}$, so the energy cost is about 0.7 yuan/W, so the cost of PV module is 0.6 yuan $/ \mathrm{W}$, the profit is up to 0.9 yuan/w. 1 yuan $\mathrm{RMB}$ is calculated to $0.15 \$$. According to the PV module service life is 25 years, the max speed development expectation of the three stages from 2020 to 2050 can be obtained as shown in Table 1 as follows.

Table 1. Development expectation of three stages of PV for PV-Max speed mode (2020-2050).

\begin{tabular}{ccccccccc}
\hline & $\begin{array}{c}\text { PV } \\
\text { Yroduct } \\
\text { Capacity } \\
\text { GW }\end{array}$ & $\begin{array}{c}\text { PV } \\
\text { Installation } \\
\text { in } \\
\text { China } \\
\text { GW }\end{array}$ & $\begin{array}{c}\text { PV } \\
\text { Installation } \\
\text { abroad } \\
\text { GW }\end{array}$ & $\begin{array}{c}\text { China annual } \\
\mathrm{CO}_{2} \text { emission } \\
\text { reduction } \\
\text { GT }\end{array}$ & $\begin{array}{c}\text { Toatal } \\
\text { annual } \mathrm{CO}_{2} \\
\text { emission } \\
\text { reduction } \\
\text { GT }\end{array}$ & $\begin{array}{c}\text { The balance of } \\
\text { payments } \\
\text { (\$billion) }\end{array}$ & $\begin{array}{c}\text { China } \\
\text { annual PV } \\
\text { power } \\
\text { generating } \\
\text { Twh }\end{array}$ & $\begin{array}{c}\text { Foreign } \\
\text { annual PV } \\
\text { power } \\
\text { genatin } \\
\text { Twh }\end{array}$ \\
\hline 2020 & 100 & & & & & -24 & & \\
2021 & 200 & & & & & -48 & & \\
2022 & 400 & & & & & -96 & & \\
2023 & 400 & 400 & & 0.4 & 0.4 & -42 & 520 & \\
2024 & 400 & 800 & & 0.9 & 0.9 & 12 & 1040 & \\
2025 & 400 & 1200 & & 1.3 & 1.3 & 66 & 1560 & \\
2026 & 400 & 1600 & & 1.7 & 1.7 & 120 & 2080 & \\
2027 & 400 & 2000 & & 2.2 & 2.2 & 174 & 2600 & \\
2028 & 400 & 2400 & & 2.6 & 2.6 & 228 & 3120 & \\
2029 & 400 & 2800 & & 3.1 & 3.1 & 282 & 3640 & \\
2030 & 400 & 3200 & & 3.5 & 3.5 & 336 & 4160 & \\
2031 & 400 & 3600 & & 3.9 & 3.9 & 390 & 4680 & \\
2032 & 400 & 4000 & & 4.4 & 4.4 & 444 & 5200 & \\
2033 & 400 & 4000 & 400 & 4.4 & 4.8 & 498 & 5200 & 520 \\
2034 & 400 & 4000 & 800 & 4.4 & 5.2 & 552 & 5200 & 1040 \\
2035 & 400 & 4000 & 1200 & 4.4 & 5.7 & 606 & 5200 & 1560 \\
2036 & 400 & 4000 & 1600 & 4.4 & 6.1 & 660 & 5200 & 2080 \\
2037 & 400 & 4000 & 2000 & 4.4 & 6.6 & 714 & 5200 & 2600
\end{tabular}




\begin{tabular}{lllllllll}
2038 & 400 & 4000 & 2400 & 4.4 & 7.0 & 768 & 5200 & 3120 \\
2039 & 400 & 4000 & 2800 & 4.4 & 7.4 & 822 & 5200 & 3640 \\
2040 & 400 & 4000 & 3200 & 4.4 & 7.9 & 876 & 5200 & 4160 \\
2041 & 400 & 4000 & 3600 & 4.4 & 8.3 & 930 & 5200 & 4680 \\
2042 & 400 & 4000 & 4000 & 4.4 & 8.7 & 984 & 5200 & 5200 \\
2043 & 400 & 4000 & 4400 & 4.4 & 9.2 & 1038 & 5200 & 5720 \\
2044 & 400 & 4000 & 4800 & 4.4 & 9.6 & 1092 & 5200 & 6240 \\
2045 & 400 & 4000 & 5100 & 4.4 & 9.9 & 1134 & 5200 & 6630 \\
2046 & 400 & 4000 & 5300 & 4.4 & 10.2 & 1164 & 5200 & 6890 \\
2047 & 400 & 4000 & 5300 & 4.4 & 10.2 & 1170 & 5200 & 6890 \\
2048 & 400 & 4000 & 5300 & 4.4 & 10.2 & 1224 & 5200 & 6890 \\
2049 & 400 & 4000 & 5300 & 4.4 & 10.2 & 1278 & 5200 & 6890 \\
2050 & 400 & 4000 & 5300 & 4.4 & 10.2 & 1332 & 5200 & 6890 \\
\hline
\end{tabular}

It can be seen that the development of the three stages of max speed mode is as follows:

1. The first three years (2020-2022) are the closed expansion period. Through PV for PV can rapid expand the production capacity .The annual PV capacity increased from $100 \mathrm{GW}$ to $400 \mathrm{GW}$, and the PV investment in this stage also increased rapidly. The investment in the first year was 24 billion dollars, the output of the year was $100 \mathrm{GW}$, and the profit was 13.5 billion dollars. After 3 years, the accumulative total investment was about 96 billion dollars.

2. The fourth year to the thirteen year (2023-2032) are the domestic expansion period. The annual production capacity is stable at $400 \mathrm{GW}$, and the installation can be promoted from areas with solar energy resources category 1 to areas with category III, with an annual net profit of 54 billion dollars. After 2032, the domestic PV installation will reach 4,000 $\mathrm{GW}$. In the following years, the annual generating capacity will be $5200 \mathrm{TWh}$, equivalent to 640 million tce, accounting for $10.7 \%$ of the national energy consumption and $36.9 \%$ of the electricity consumption.

3. After the 14th year (2033-2048) are the export period. The net profit of export sales is 360 billion dollars every year. Since PV modules have 25-year life span, it will be necessary to replace $100 \mathrm{GW}$ of old equipment in 2045 , and so on, until the completion of $400 \mathrm{GW}$ of PV equipment in 2047. By 2046, a total of 5300GW of pv can be sold to foreign countries, with an annual power generating as high as $6890 \mathrm{TWh}$, equivalent to 850 million tce.

4. Due to $400 \mathrm{GW}$ of equipment be replaced every year after 2047 , So the PV installation has remained stable since then. It will be a balance between supply and demand, and annual net income of 54 billion dollars. By 2050, the cumulative net income has reached 1332 billion dollars, about 13.9 times the maximum cumulative investment.

5. In addition, the annual $\mathrm{CO} 2$ emission reduction by $\mathrm{PV}$ power generation is huge. After 2023, the annual emission reduction of domestic PV power generation will increase by about $0.3 \mathrm{GT}$ every year, and after 2032, the annual emission reduction of domestic PV power generation will increase by $4.4 \mathrm{GT}$. The emission reduction of total PV power generation will increase continuously until $10.2 \mathrm{GT}$ in 2046, and the annual CO2 emission reduction will be maintained stable thereafter. This plan will reduce China's emissions by 102.6 GT and word's emissions by 171.2 GT by 2050 . So this plan will not only benefit China, but also benefit the world.

\section{The region selection of PV plant}

According to the results of the fourth national desert survey completed in 2011, by the end of 2009, the desertified land area in China was $263.62 \times 10^{4} \mathrm{~km}^{2}$, and the desertified land area was $173.11 \times 10^{4} \mathrm{~km}^{2}$, accounting for $27.43 \%$ and $18.03 \%$ of the total land area 
respectively[14]. Desert areas have harsh climate, heavy wind and dry sand, little precipitation, little vegetation, sparsely populated, abundant sunshine, and solar radiation greater than $1700 \mathrm{kWh} / \mathrm{m}^{2}$. Solar radiation belongs to category 1 resource area, making it a good place to build PV plants.

The wind energy density in the three northern regions is generally above $150 \mathrm{~W} / \mathrm{m}^{2}$, and the annual cumulative wind speed of $3 \mathrm{~m} / \mathrm{s}$ is more than $4000 \mathrm{~h}$. In particular, the wind energy density in northern Inner Mongolia and Gansu is as high as $200-300 \mathrm{w} / \mathrm{m}^{2}$, and the annual cumulative wind speed of $3 \mathrm{~m} / \mathrm{s}$ is more than $5000 \mathrm{~h}$. According to the average annual power generation of $1 \mathrm{~W}$ wind turbines in the region, the annual installed wind power capacity of $1 \mathrm{~W}$ can produce $2 \mathrm{~W}$ PV products. In addition, Wind and solar power are complementary in northwest China: the wind is usually stronger in the early morning and night than during the day, and stronger in winter and spring than in summer and autumn, while solar power is the opposite. Secondly, wind power and PV power are intermittent power generation, while the three north areas of China is rich in natural gas resources, which can be supplemented by the construction of distributed natural gas power stations to realize the stable production of PV plants. Therefore, if wind-solar complementary power generation is adopted to produce PV locally, the annual pv output will be greatly improved.

The combination of PV power station and vegetation can not only prevent wind and fix sand, but also greatly improve solar energy utilization rate. The energy conversion efficiency of local PV power generation is hundreds of times that of vegetation in desert areas. It is estimated that the solar energy converted by $1 \mathrm{~m}^{2} \mathrm{PV}$ panels is equivalent to the solar energy utilization of $260.8 \mathrm{~m}^{2}$ desert vegetation in Minqin sand area[15]. In 1982 2015, Shanxi, Qinghai, Ningxia, Gansu, Chongqing (Zhejiang), Xizang, Jiangsu and Xinjiang (Shaanxi and Sichuan) are the fastest annual average temperature rise in China, with the average temperature rising by $0.57^{\circ} \mathrm{C}, 0.53^{\circ} \mathrm{C}, 0.49^{\circ} \mathrm{C}, 0.48^{\circ} \mathrm{C}, 0.46^{\circ} \mathrm{C}, 0.42^{\circ} \mathrm{C}$, $0.40^{\circ} \mathrm{C}, 0.39^{\circ} \mathrm{C}$ per 10 years. Among the top 11 provinces with the fastest warming in China, only Chongqing, Zhejiang and Jiangsu are not in the three northern regions[16]. So the development of PV in the three northern regions is conducive to reducing the local fossil energy exploitation and anthropocentric thermal emissions, mitigating local climate warming, and protecting the ecology and environment of China's border areas.

PV plants can also be combined with desertification prevention and control, ecological agriculture, ecological tourism and poverty alleviation. At present, the ratio of sand control area and PV installation area in China's desert PV industrial parks is generally between 3.813.3. The 400GW PV module covers an area of $2,000 \mathrm{~km}^{2}$. If calculated according to the PV power generation area and desertification control area of 1:6, it can promote the desert control of $12,000 \mathrm{~km}^{2}$, only accounting for $2.3 \%$ of the treatable area of China's desertification land (about 530,000 $\mathrm{km}^{2}$ ), which is equivalent to two times of Shanghai . Due to the electricity price in western China is cheaper, at present the production capacity of crystal silicon and silicon wafer in China is shifting to northwest and southwest of China, which is completely consistent with the region selection of this plan. The construction of PV plants in the three northern regions can turn local resources into gold, and the western Gobi desert can be turned into a "green valley".

\section{Conclusion}

In view of the investment difficulties faced by China and the world in achieving carbon neutrality. This paper studied the innovative development mode of PV for PV. After 2022, China's annual PV capacity can reach $400 \mathrm{GW}$, with the largest cumulative total investment of about 96 billion dollars, and the annual profit of 54 billion dollars thereafter. After 2032, China PV installation can achieve 4TW, with 5200TWh of electricity generation, and 4.4 billion tons of $\mathrm{CO} 2$ emission reduction annually. After 2033, it will be available for export. 
By 2046, it will be available for 5.3TW of foreign PV installations, generate 6890TWh of electricity annually, and reduce emissions by 10.2 billion tons of $\mathrm{CO} 21.2$ billion tons annually. By 2050, the total CO2 emission reduction will be 102.7 billion tons for China and 171.2 billion tons for the world. By 2050 the accumulative net income will be 1332 billion dollars, which is about 13.9 times of the largest accumulative investment. The economic and ecological benefits of PV for PV are huge. If the PV plant is built in the three northern regions of China, combined with desertification control, the western Gobi desert will become a "green valley".

\section{Reference}

1. World Bank. The development status and future trends of carbon pricing mechanism 2020. DOI:10.1596/978-1-4648-1586-7.

2. Global Energy Interconnection Development Cooperation Organization. China's Carbon Peak Research Report by 2030. 2021. https://www.geidco.org.cn/.

3. International Energy Agency (IEA). World Energy Statistics. https://www.iea.org/classicstats/relateddatabases/worldenergystatistics/(2019).

4. Goldman Sachs. Corbonomics: China net zero: the clean tech revolution. 2021.

5. Hector Pollitt.Analysis: Going carbon neutral by 2060 'will make China richer'.[EB/OL].https://www.carbonbrief.org/analysis-going-carbon-neutral-by-2060will-make-china-richer.

6. K. Hansen et al. Status and perspectives on $100 \%$ renewable energy systems. Energy 175 (2019) 471-480. https://DOI.org/10.1016/j.energy.2019.03.092.

7. IEA. The role of energy efficiency: perspectives for the energy transition [ EB/OL ]. https://www.iea.org/reports/the-role-of-energy-efficiency, 2018-04/2019-11.

8. BCG.China Climate Path Report [EB/OL] .https://www.sohu.com/a/420782503_308956.

9. Wood Mackenzie.China's carbon neutral" target may cost 35 trillion yuan[EB/OL]. https://www.sohu.com/a/420782503_308956.

10. Lauri Myllyvirta, How China can achieve its 'carbon neutrality' goal.https://www.carbonbrief.org/.

11. Sohu.PVs: "14th Five-Year Plan" renewable energy main line layout field[EB/OL]. https://www.sohu.com/a/428304329_418320.

12. Ji-Feng Li, Zhong-Yu Ma, Ya-Xiong Zhang, et al. Analysis on energy demand and $\mathrm{CO}^{2}$ emissions in China following the Energy Production and Consumption Revolution Strategy and China Dream target. 2018, 9(1):16-26. DOI:10.1016/j.accre.2018.01.001.

13. Bjarne Steffen.Estimating the cost of capital for renewable energy projects. Energy Economics 88 (2020) 104783. https://DOI.org/10.1016/j.eneco.2020.104783.

14. State Forestry Administration. Bulletin of Desertification and Desertification in China . China Green Times.2011-01-05.

15. LIU Shizeng, CHANG Zhaofeng, ZHU Shujuan, etc, Ecological Significance of PV Power Plants in the Desert and Gobi. Ecological Economy,2016,32(02):177-181.

16. Jin Kai. Temporal and spatial changes of vegetation cover in China and its relationship with climate and human activities. Northwest Agriculture and Forestry University. 